\title{
Localized spontaneous fluctuations of electric potential in shoots of different plants
}

\author{
KRZYSZTOF GLĘBICKI*. ZYGMUNT HEJNOWICZ**. ANDRZEJ PIJANOWSKI*
}

* Botanical Garden of the Polish Academy of Sciences, Prawdziwka 2, 00-973 Warsaw, Poland

** Agricultural University Lublin. Division in Zamość. H. Sawickiej 3, 22-400 Zamość, Poland

(Received: July 8. 1985. Accepted: October 14. 1985)

\begin{abstract}
Sharp short-lasting voltage fluctuation is one of the components of plant electric activity. Common appearance of such fast signals (FS) in the stems of several species has been found. Observed spatial distribution of its amplitude excludes the possibility of an artefact, deriving from the electrode surface-plant tissue interaction. The hypothesis that FS are due to action potential of a single cell or a small group of cells observed in a volume conductor is considered.
\end{abstract}

Key words: action potential, excitable cells, electric activity

\section{INTRODUCTION}

A cell in a multicellular organ is surrounded by its cell wall and by other cells. The cell wall is a part of the apoplast - a continuous network consisting of organ structures outside the plasmalemma of cells - which, being saturated with a fluid containing motile ions, is able to conduct an electric current. If the cell undergoes changes of its transmembrane potential $\left(\mathrm{E}_{n}\right)$ it may become a source of an electric current which flows through the apoplast and, to a limited extent also through inactive cells. One deals then with a "volume conductor" - a system in which a source of a current is immersed in a conducting medium. The current between two points of the volume conductor indicates the existence of a potential difference (voltage) between these points. The relation between the voltage and the change of $\mathrm{E}_{n}$ is not simple: on one hand, the current in the volume conductor varies in time and space, on the other, there is a spatial- 
-temporal pattern of the $\mathrm{E}_{n}$ change. Some properties of the electric field in the volume conductor such as the fast falling of the amplitude with distance from the source, or appearance of positive and negative spikes, may be anticipated with the use of a simple model related to the action potential in neurons (Patton and Woodbury 1965, Lorente de No 1947). The geometry of plant cells connected by plasmodesmata into a symplast is, however, much more complicated than in a cylindrical neuron. The electrical space constant of a plant cell is so large in comparison with the cell dimension, that the cell must behave nearly as a unit during depolarization of its membrane. For this reason, the action potential of a plant cell probably does not generate any signal measurable in a volume conductor. However, the minute plasmodesmata connections between excited and not excited cells may have properties of potential sources recordable in a volume conductor. The situation may be similar to the case of cell bodies and dendritic extensions of brain cortical cells, considered in the context of an electroencephalographic record. The volume conductor recording of the activity of the brain cortical layer can be done easily, however, interpretation of the origin of recorded signals is very difficult (Towe 1965).

In a previous paper (Hejnowicz et al. 1986) we reported results of simultaneous recording from a lupine stem by means of a DC amplifier and a band-pass amplifier, both connected to the same electrode inserted into the stem. When the potential fluctuation elicited by application of an auxin drop to a cut petiole was passing the electrodes' level, the DC amplifier showed a decrease of the potential for $20-80 \mathrm{mV}$ in the form of a relatively long-lasting pulse. At the same time the band-pass amplifier showed one to a few pairs of spikes whose amplitudes were usually much less than $1 \mathrm{mV}$, and which concurred with the upstroke phase of the pulse. We have interpreted these spikes as the action potential-of certain excitable cells recorded in a volume conductor and the pulse as a wave of cooperative depolarization of excitable and a mass of inexcitable cells. This interpretation implies the existence of excitable cells among a predominating number of inexcitable cells. If so, we may expect that the excitable cells, single or in groups may spontaneously fire a local action potential, that is, one which does not evoke the depolarization of neighbouring cells to a high enough degree to trigger the firing of the next excitable cells. This action potential should be recordable by means of a band-pass amplifier and would be of the "in volume conductor" type. Indeed, the records from intervals when no stimulation was applied showed the occurance of spikes which resembled those accompanying the propagation pulse. Further experiments showed that similar spikes also occur in the shoots of other species. This paper deals with these signals. 


\section{MATERIAL AND METHODS}

The following species were used: Solanum tuberosum, Phaseolus vulgaris, Lupinus sp., Hibiscus rosa-sinesis, Cucurbita maxima, Pelargonium sp., Dianthus, Coleus, Tradescantia, Robinia pseudoacacia, Caragana arborescens. Excised shoots of the last two species were dipped by their basal end in water. Others grew in pots. The plants for recording were placed inside a Faraday cage $2 \times 2 \times 2 \mathrm{~m}$. Except for the preamplifier, there was no electric equipment in the cage. The other parts of the recording system - a type WSB-4 four channel biological amplifier, an oscilloscope and a multichannel chart recorder were outside of the cage. The amplifier was working in a frequency band width of $0.1-100 \mathrm{~Hz}$. Filter for $50 \mathrm{~Hz}$ was applied. The electrode was made of $0.3 \mathrm{~mm}$ diameter silver wire, sharpened and electrochemically covered with $\mathrm{AgCl}$. Electrodes were inserted into the stem, about $1 \mathrm{~mm}$ deep (sometimes deeper). A system of 5 or more electrodes placed along the stem or some of them in a whorl was used. The longitudinal distance between two successive electrodes was 3-20 mm. The recording began shortly after inserting the electrode to examine the post-wound effects and was continued for several days without changing the electrode insertions; the recording was, however, done during daytime, 3-8 hours continously. The plant in the cage was in a 12 hour "artificial day"

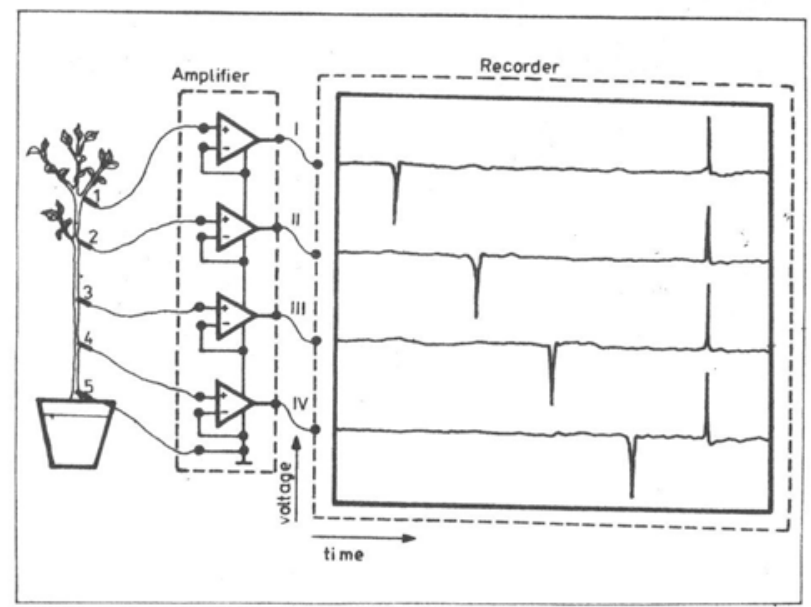

Fig. 1. The scheme of measuring system I. The electrodes 1, 2, 3 and 4 are connected to noninverting inputs (+) of the amplifiers. The signals deriving from these electrodes appear in output channels I, II, III and IV of amplifiers with original polarity. Electrode 5 is connected to inverting inputs of all amplifiers. The signal deriving from this electrode is seen in all four output channels of the amplifiers (recorder) simultaneously, with inverted polarity. Negative signals appearing sequentially on the series of electrodes are shown 
If both of the electrodes of a pair connected to an amplifier are inserted in a plant, the polarity of the recorded signals has two possible interpretations, i.e. a negative output signal may be due to either a negative input signal on a nonreversing input or to a positive one seen by the electrode connected to a reversing input. By looking on such a record, we are unable to determine either from which electrode the signal derived or what the signal polarity was. This trouble can be eliminated if a system of appropriately connected amplifiers is used instead of a series of separate amplifiers. Two systems were applied alternatively. In the case of system I (Fig. 1), a signal deriving from a common electrode is seen simultaneously in all channels of the recorder. Therefore in this system the common electrode should be placed in a low activity tissue. If such a place cannot be found, system II (Fig. 2) is preferable. A change from one system

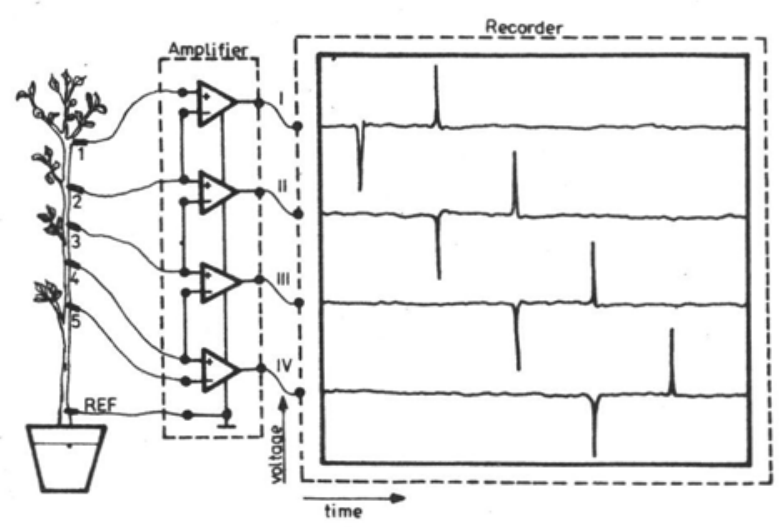

Fig. 2. System II. The scheme of measuring system II. Electrode 1 is connected to the input $(+)$ of the amplifier I. The input (-) of this amplifier is connected to the input (+) of amplifier II. Similarly, remaining amplifiers have inputs (+) and (-) coupled, so that each of electrodes 2, 3 and 4 has a connection to two neighbouring amplifiers. Electrode 5 is connected to the input (-) of amplifier IV only. The signal deriving from electrode 1 appears in channel I with original polarity. Signals from electrode 5 are seen in channel IV with inverted polarity. The signal from electrode 2 is seen in channel I with inversed polarity and simultaneously in channel II with original polarity. The record of the signals deriving from electrodes 3 and 4 are similar. Negative signals appearing sequentially on the series of electrodes are shown on the record

to another was achieved without any manipulation of the electrodes, only the electrical connections were changed. The choice of the system depends on the electrical activity of the stem and on the size of the region in which a signal could be seen simultaneously. 


\section{RESULTS}

Typical records of the electric activity in stems of all of the studied plants are shown on Figs. 3 and 4. The most common shape of a signal is a triphasic spike beginning with the negative highest component. The last

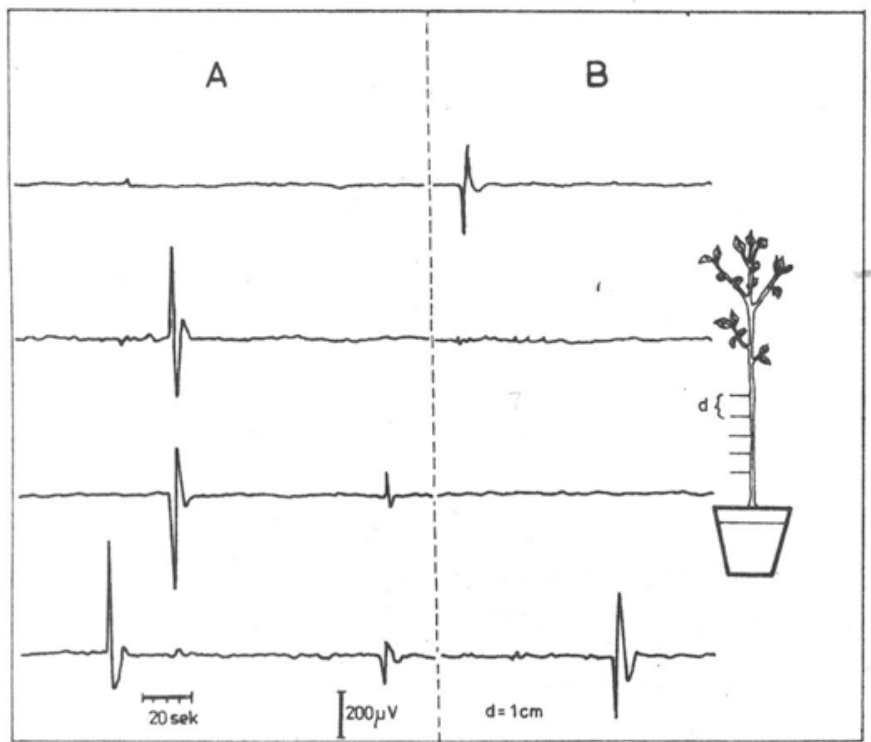

Fig. 3. Examples of recordings of electric activity in Pelargonium. A - First day; system II. B - Second day; system I

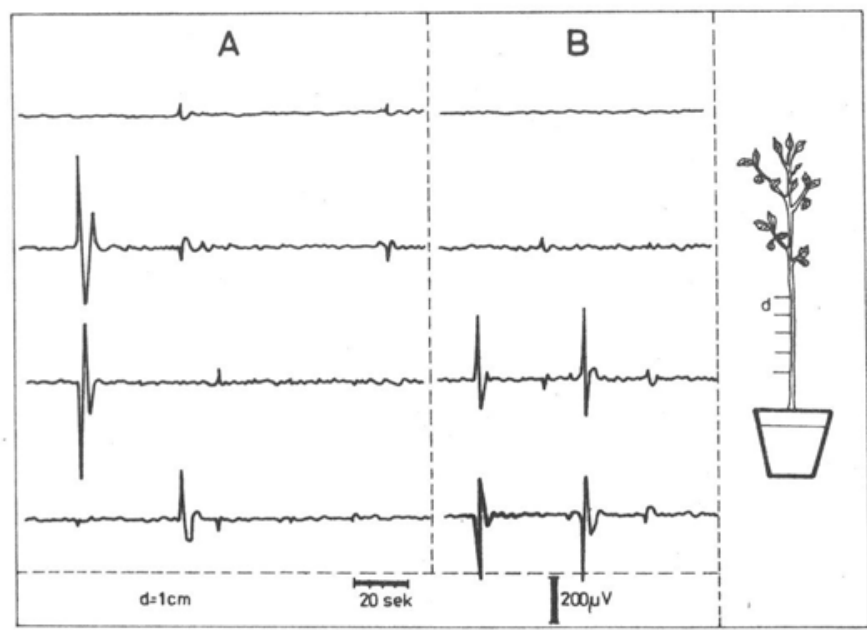

Fig. 4. The record of electric activity in Solanum tuberosum. A-First day; system II. B - Third day; system II 
component, also negative, is the lowest, sometimes not appreciable at all. The duration of the signal is short in comparison to the duration of the symplastic compound of the action potential spike obtained by means of a DC amplifier and comparable with the oscillatory component of the action potential (Hejnowicz et al. 1986). We shall call it the "fast signal" (FS). The FS appeared with extremely varying frequency. In Coleus and Tradescantia the frequency was very low (of the order ten signals per hour). However, we are not able to conclude that this is a general feature of these species because only a few plants of each were examined. On the other hand, the FS frequency in the remaining species varied even in a single plant during a one day-course of recording. Sometimes the frequency was so high that it was difficult to analyse the signals. The amplitude of the spikes was also variable, mostly in the range from a few to $200 \mu \mathrm{V}$, the highest were $2-3 \mathrm{mV}$. The FS do not appear in thermally killed stems. The long time characteristics of FS (frequency, amplitude) are not obviously related to any physiological factor like illumination, temperature, humidity. The electric activity for several minutes after driving the electrodes into the plant was different from that occuring further on and was not taken into account in this study. In order to determine the size and localization of the region generating FS (which below is called the source region)

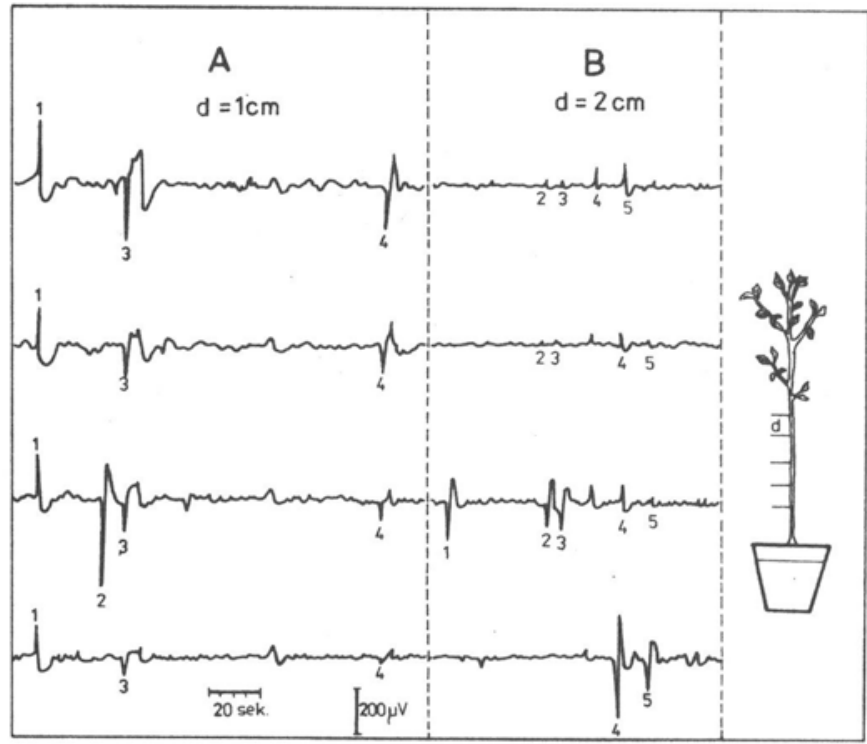

Fig. 5. Electric activity in Phaseolus vulgaris. System I. The estimation of the disturbed region dimension (z). A1, A2-z=1 cm; A3, A4-z>3 cm; B1, B4, B5-z>2 cm; B2, B3 $-z>4 \mathrm{~cm}$. For instance, in the B4, the signal is seen by electrode 4 and by electrode 5 (Ref). The signal from the reference electrode is lower than that from electrode 4 and appears with inversed polarity in the remaining channels 


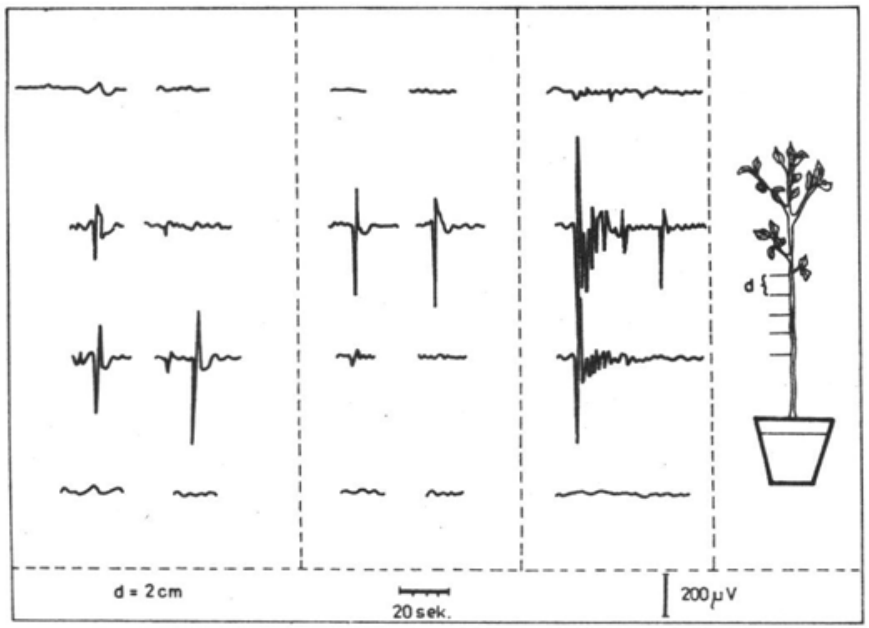

Fig. 6. Electric activity in Phaseolus vulgaris. System I. Examples excluding the electrode surface as a possible source of FS. Observe that in each record one signal was seen on two electrodes while the other was not, though its amplitude was higher

recording with different locations of the electrodes was done. Figure 5 shows the record obtained by means of a longitudual series of electrodes spaced 10 and $20 \mathrm{~mm}$ one from the other. The smaller the distance between the electrodes was, the more often the FS source region was seen simultaneously by neighbouring electrodes. The relation between the simultaneous appearance of FS and the distance between the electrodes is, however, not strong even in the same species which suggests that the longitudinal size of the source varies. In Phaseolus, the FS were usually seen simultaneously on two electrodes when the longitudinal distance was not greater than $20 \mathrm{~mm}$. In Hibiscus, Solanum, Pelargonium this distance was $30 \mathrm{~mm}$, $5 \mathrm{~mm}$ and $5 \mathrm{~mm}$, respectively. This comparison suggests that the longest source region was in Hibiscus, the shortest in Pelargonium and Solanum. In the case of the electrodes located on a whorl, so that the distance between them was 3-4 $\mathrm{mm}$ transversely, a simultaneous appearance of FS on two neighbouring electrodes was much less frequent than on two longitudinal electrodes even more distant. This suggests that the transverse dimension of the source region is much smaller than the longitudinal one. A more detailed study in this respect will be made. The result of this study excludes the electrode surface as a source of FS. Especially clear in this respect are combinations of spikes like those in Fig. 6. A combination consists of signals with different amplitudes, and such that signals of a lower amplitude were seen by two neighbouring electrodes, but slightly later, a signal of a higher amplitude on one electrode was not seen by the second electrode. 
Sometimes regular trains of repetitive spikes were observed (Fig. 7). Whether the spikes in this series are similar to the FS described earlier is not sure. The result presented on Fig. 7 was obtained by means of system II. For the sake of description, the period of recording may be divided into 2 intervals:

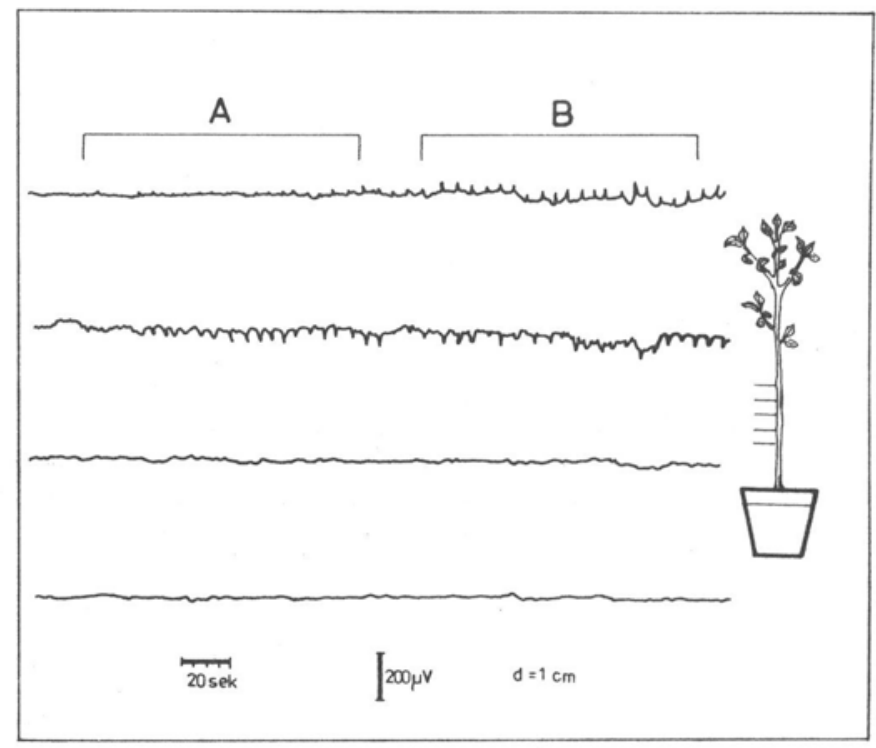

Fig. 7. Electric activity of Dianthus in the form of regular trains of repetitive spikes. Two intervals: $\mathrm{A}$ and $\mathrm{B}$ are delineated for the sake of description in the text. System II

A. The signals of negative polarity were seen both by electrodes 1 and 2 , but the latter with a lower amplitude (the negative signal on electrode 1 made the positive spikes in channel 1 lower).

B. The signals were seen by electrode 2 only (the positive spikes in channel 1 are of a similar amplitude as the negative spikes in channel 2). The following interpretations are possible:

1. The activity of the source region was displaced in the direction from electrode 1 to electrode 2, starting from a point closer to electrode 2 .

2. The lower boundary of the source region, which was closer to electrode 2, did not move, while the upper boundary moved downwards.

Similar trains of repetitive spikes as in Fig. 7 have been observed in other plants, especially in Lupinus and Sinapis which were being recorded for many hours. However, the appearance of such trains is completely unpredictable, exept that there is a high probability that it will happen during a sufficiently long period of recording, 8 hours or so per pair of electrodes. 


\section{DISCUSSION}

This paper excludes the possibility that the considered signals (FS) are artefacts occuring on the electrode surface: they represent electrical activity at sites located in live tissues at different positions with respect to the electrode. This activity is thus recorded in a volume conductor. It is our hypothesis that this activity is the action potential in individual or a chain of excitable cells, but in fact, we indicate action potential because we do not know other electrical activities which would be recordable in a volume conductor. Assuming that it is the action potential, a question appears concerning which part of the membrane produces the signal. A plant cell is expected to undergo AP as a unit, thus such an AP should not be recordable in a volume conductor. The candidates are the plasmodesmata between the cell undergoing AP and the neighbouring resting cells: they may possess the necessary dipolar properties. Are the FS homologous with the oscillatory component of the propagating pulse described in our previous paper? There is some similarity between the signals and the spikes of the oscillatory component, however there are also differences. In general, the duration of FS spikes is shorter, the first spike is more often negative and is more pronounced than the first spike in OC in the case when it is negative. We can answer the question only in this way that the homology of $\mathrm{FS}$ and $\mathrm{OC}$ is probable. Maybe the shape of $\mathrm{OC}$ is affected by the propagation of the pulse.

The appearance of signals which are very similar to FS has been reported by Karlsson (1972) in shoots of Ficus elastica using a band-pass amplifier and polarizable electrodes. Pickard $(1972,1973)$ and also Karlsson (1972) have reported occurrence of voltage fluctuations similar to those in Fig. 7 in several plants. Pickard (1973) restrained from suggesting the identity of the repetitive fluctuation she observed with those observed by Karlsson, because the former were observed by means of a nonpolarizable electrode and without removing the nonoscillatory component of potential change. Our recording was done by means of a nonpolarizable electrode on one hand and a band-pass amplifier on the other. It is thus highly probable that the repetive fluctuations in all three papers represent the same phenomenon. Our observation of the movement of the source of these fluctuations adds. a spatial aspect to the phenomenon. Pickard (1972) suggested that the fluctuations may be the action potential of a single cell, we are of the same opinion because there is no better explanation.

If there is a spontaneous local action potential in cells, the question of function arises. Gradmann and Mummert (1980) have suggested that action potential may have developed for primary direct function in ionic regulation: the permeability increase during an action potential allows the 
elease of substantial amount of ions. This hypothesis seems to be especially interesting if the excitable cells in the lupine stem were in the protoxylem and protophloem as in the Mimosa petiole (Sibaoka 1962).

\section{REFERENCES}

Gradmann D., Mummert H., 1980. Plant action potentials. In: Plant membrane transport: Current conceptual issues. Spanswick R. M., Lucas W. J., Dainty J. (eds.). Elsevier/N. Holland Biomed. Press, Amsterdam-Oxford. pp. 333-348.

Hejnowicz Z., Pijanowski A., Głębicki K., 1986. An oscillatory component of propagated fluctuation of electric potential in lupine shoot. Acta Soc. Bot. Pol. 55: 53-66. Karlsson L., 1972. Nonrandom bioelectrical signals in plant tissue. Plant Physiol. 49: 982-986.

Lorente de No R., 1947. Analysis of the distribution of the action currents of nerve in the volume conductor. Stud. Rockefeller Inst. Med. Res. 132: 384-482.

Patton H. D., Woodbury J.W., 1965. Special properties of nerve trunks and tracts. In: Physiology and biophysics. Ruch. T. G., Patton H. D., (eds.). Saunders Comp., Philadelphia. pp. 73-94.

Pickard B. G., 1972. Spontaneous electrical activity in shoots of Ipomea, Pisum and Xanthium. Planta 102: 91-114.

Pickard B. G., 1973. Action potentials in higher plants. Bot. Rev. 39: 172-201.

Sibaoka T., 1962. Excitable cells in Mimosa. Science 137: 226.

Towe A. L., 1965. Electrophysiology of the celebral cortex: cosciousness. In: Physiology and biophysics. Ruch T. G., Patton H. D., (eds.). Saunders Comp., Philadelphia. pp. 455-464.

Spontaniczne, lokalne zaburzenia potencjalu elektrycznego $w$ lodygach roślin

\section{Streszczenie}

Jednym ze składników obrazu elektrycznej aktywności roślin są krótkotrwałe zaburzenia potencjału o charakterystycznym, ostrym kształcie. Stwierdzono występowanie tego typu sygnałów (FS) u roślin wszystkich obserwowanych gatunków. Rozkład przestrzenny amplitud FS wyklucza możliwość artefaktu związanego z oddziaływaniem powierzchni elektrody z tkanką roślinną. Rozważana jest hipoteza, że źródłem FS są pojedyncze komórki lub grupy komórek, generujące potencjał czynnościowy. Zjawisko takie, obserwowane w przewodniku objętościowym, może wywołać efekt podobny do obserwowanych FS. 